\title{
NISCH Gene
}

National Cancer Institute

\section{Source}

National Cancer Institute. NISCH Gene. NCI Thesaurus. Code C101381.

This gene is involved in imidazoline binding and signaling. 